\title{
๖The Fate of the Southern Weddell Sea Continental Shelf in a Warming Climate
}

\author{
Hartmut H. Hellmer, Frank Kauker, ${ }^{a}$ Ralph Timmermann, and Tore HattermanN \\ Alfred Wegener Institute Helmholtz Centre for Polar and Marine Research, Bremerhaven, Germany
}

(Manuscript received 30 May 2016, in final form 27 January 2017)

\begin{abstract}
Warm water of open ocean origin on the continental shelf of the Amundsen and Bellingshausen Seas causes the highest basal melt rates reported for Antarctic ice shelves with severe consequences for the ice shelf/ice sheet dynamics. Ice shelves fringing the broad continental shelf in the Weddell and Ross Seas melt at rates orders of magnitude smaller. However, simulations using coupled ice-ocean models forced with the atmospheric output of the HadCM3 SRES-A1B scenario run $\left(\mathrm{CO}_{2}\right.$ concentration in the atmosphere reaches 700 ppmv by the year 2100 and stays at that level for an additional 100 years) show that the circulation in the southern Weddell Sea changes during the twenty-first century. Derivatives of Circumpolar Deep Water are directed southward underneath the Filchner-Ronne Ice Shelf, warming the cavity and dramatically increasing basal melting. To find out whether the open ocean will always continue to power the melting, the authors extend their simulations, applying twentieth-century atmospheric forcing, both alone and together with prescribed basal mass flux at the end of (or during) the SRES-A1B scenario run. The results identify a tipping point in the southern Weddell Sea: once warm water flushes the ice shelf cavity a positive meltwater feedback enhances the shelf circulation and the onshore transport of open ocean heat. The process is irreversible with a recurrence to twentieth-century atmospheric forcing and can only be halted through prescribing a return to twentieth-century basal melt rates. This finding might have strong implications for the stability of the Antarctic ice sheet.
\end{abstract}

\section{Introduction}

The southern Weddell Sea continental shelf (Fig. 1) is a key region of the World Ocean with regard to the formation of the precursors of Antarctic Bottom Water. The shelf water characteristics are defined by 1) brine rejection from strong sea ice formation resulting in dense, saline shelf water (Nicholls et al. 2008; Haid and Timmermann 2013) and 2) melting/freezing at the base of the Filchner-Ronne Ice Shelf (FRIS), producing ice shelf water (ISW), a component of the Weddell Sea Deep and Bottom Waters (Foldvik et al. 2004). At present, saline shelf water is the sole water mass fueling

¿ Denotes content that is immediately available upon publication as open access.

Ice2sea Contribution Number 167.

a Additional affiliation: OASys, Hamburg, Germany.

Corresponding author e-mail: Hartmut H. Hellmer, hartmut. hellmer@awi.de basal mass loss (BML) beneath FRIS (Nicholls 1997), which remotely sensed observations estimate as lying in the range $50 \pm 40$ (Depoorter et al. 2013) to $155 \pm$ $45 \mathrm{Gt} \mathrm{yr}^{-1}$ (Rignot et al. 2013). The relatively warm water of open ocean origin rarely reaches the southern Weddell Sea ice shelf fronts (Årthun et al. 2012). This is in contrast to the Amundsen and Bellingshausen Seas, where derivatives of Circumpolar Deep Water (CDW) flush the continental shelf and reach the fringing ice shelf fronts with temperatures of over $1^{\circ} \mathrm{C}$ (Jacobs et al. 2011; Nakayama et al. 2013). There, in the southeast Pacific Ocean, the onshore flow is supported by the close proximity of the southern flank of the Antarctic Circumpolar Current (ACC) to the continental shelf (Orsi et al. 1995).

The southern Weddell Sea continental shelf is far from the southern ACC front. A clockwise gyre circulation causes CDW derivatives to enter the Weddell Sea from the east (Schröder and Fahrbach 1999; Ryan et al. 2016) and continue as warm deep water (WDW), with temperatures of about $0.8^{\circ} \mathrm{C}$, along the continental slope all the way to the tip of the Antarctic Peninsula (Fig. 1). A deep-reaching slope front separates the WDW from the continental shelf (Gill 1973), where temperatures are predominately near the surface freezing point 


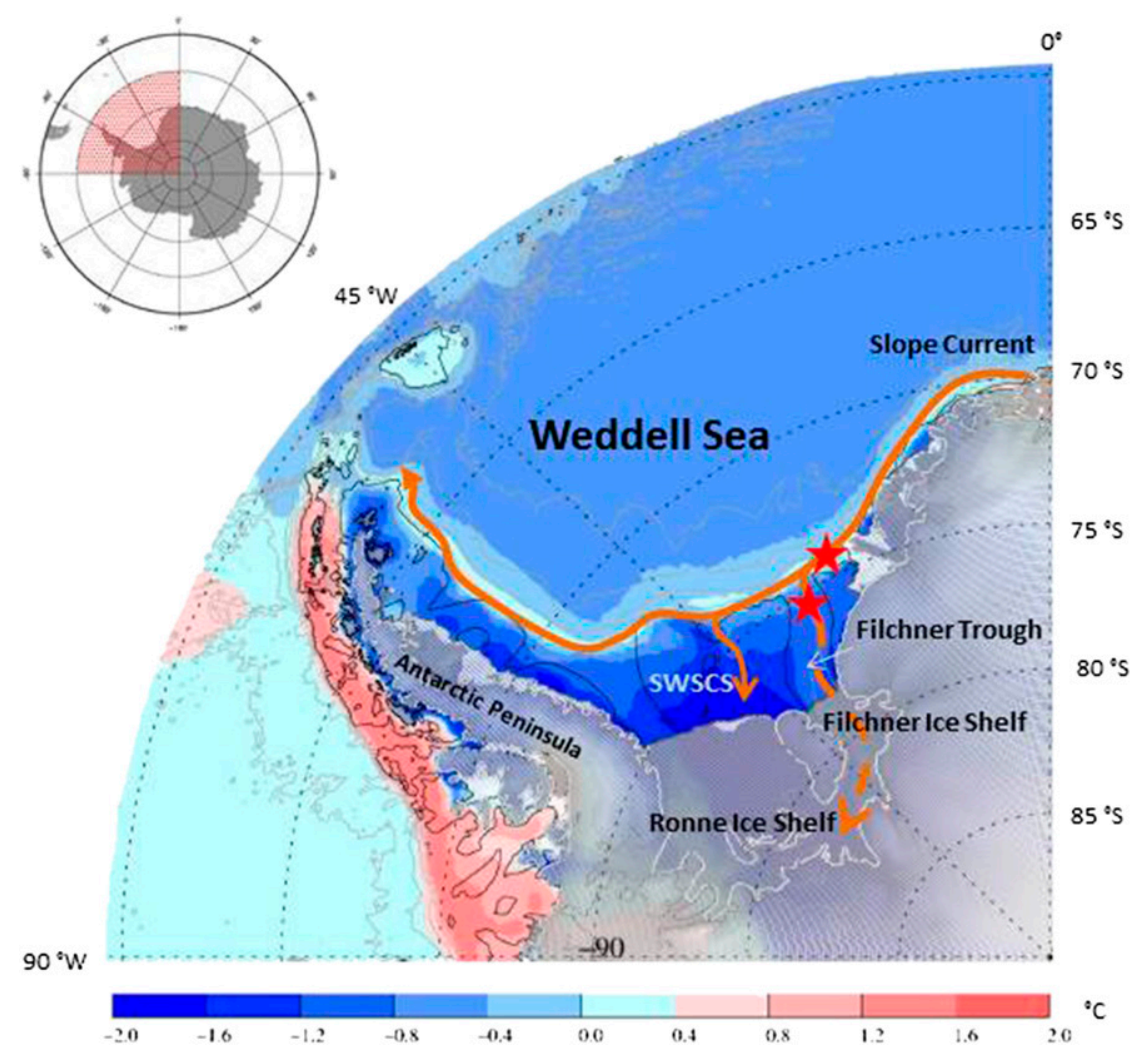

FIG. 1. Southern Ocean bathymetry and observed bottom potential temperature south of $60^{\circ} \mathrm{S}$. Bathymetry is based on RTopo-1 (Timmermann et al. 2010) with contour lines at 500 (black) and at 1000, 2000, 3000, and $4000 \mathrm{~m}$ (gray). Bottom temperature is based on NOAA's World Ocean Atlas 2001. Solid orange arrows mark today's course of the slope current in the Weddell Sea and the flow of modified warm deep water onto the southern Weddell Sea continental shelf (SWSCS). The pulsing into the Filchner Trough and propagation toward the southern grounding line (light gray), as projected for the twentieth century, is indicated by the dashed orange arrow. The positions of the profiles used for analyzing the processes across the Filchner Trough Sill (FTS) (Fig. 9) are marked as red stars. Inset shows map location within the Southern Ocean.

of $-1.89^{\circ} \mathrm{C}$-which we define as today's "cold-shelf phase." Only traces of diluted WDW follow the eastern flank of two troughs, intersecting the continental shelf break at $33^{\circ}$ and $44^{\circ} \mathrm{W}$ (Fig. 1), and reach the FRIS front with a maximum temperature of $-1.3^{\circ} \mathrm{C}$ (Foldvik et al. 1985; Nicholls et al. 2008). The more pronounced eastern trough, named the Filchner Trough (FT), slopes from $600 \mathrm{~m}$ at the shelf break $\left(74.5^{\circ} \mathrm{S}\right)$ to more than $1600 \mathrm{~m}$ at the southern grounding of the FilchnerRonne Ice Shelf $\left(83^{\circ} \mathrm{S}\right)$. The onshore heat transport is controlled by a delicate interplay of the slope front with the shelf break topography and the processes inside the Filchner Trough. Here, water properties and circulation are directly linked to ocean-atmosphere interaction and related sea ice processes on the southern Weddell Sea continental shelf (SWSCS) and meltwater outflow from underneath FRIS (Grosfeld et al. 2001; Nicholls et al. 2001). The depth of the thermocline, which interacts with the Filchner Trough, is set by the frontal dynamics that are controlled by winds (Sverdrup 1954), eddy processes (Nøst et al. 2011; Stewart and Thompson 2015), and hydrographic forcing due to precipitation, sea ice, and ice shelf melting (Hattermann et al. 2014; Zhou et al. 2014) as WDW is advected westward from farther upstream along the coast.

Observations suggest that the WDW in this region is currently rising at a rate of several meters per year (Schmidtko et al. 2014), and numerical studies indicate that a warmer atmosphere causing reduced sea ice formation during the twenty-first century can change the shelf circulation such that unmodified WDW is directed southward underneath the FRIS (Hellmer et al. 2012; Timmermann and Hellmer 2013), flushing the entire ice shelf cavity with water at temperatures above $0^{\circ} \mathrm{C}$-in the following defined as the "warm-shelf phase." For a time-independent ice shelf thickness distribution this 
drives a 20-fold increase in basal melting. According to a 1100-yr coupled ocean-ice shelf/sheet simulation, which considers a time-variant cavity geometry, this heat fuels melting at the deep southern base, causing ice shelf thinning by up to $1000 \mathrm{~m}$, a retreat of the grounding line, and an acceleration of the feeding ice streams.

Because of the implications for the stability of the Antarctic Ice Sheet draining into the FRIS, the question arises whether the enhanced mass loss at its base can be stopped or at least reduced to present-day values to allow a readvance of the grounding line. For example, would a return to cooler, drier twentieth-century conditions alone or in combination with other changes be sufficient to reestablish dense shelf water, which prevents the slope current from entering the continental shelf? Plausible answers should be related to processes controlling the hydrography in the southern Weddell Sea and, though not addressed in this paper, the dynamics of the fringing ice sheet.

\section{Model description and experimental design}

We use the Bremerhaven regional ice-ocean simulations (BRIOS) model (Timmermann et al. 2002), the same as was employed for the simulations of Hellmer et al. (2012). BRIOS is a coupled ice-ocean model resolving the Southern Ocean south of $50^{\circ} \mathrm{S}$ at $1.5^{\circ}$ zonally and at $1.5^{\circ} \times \cos \phi($ where $\phi$ represents latitude) meridionally. The water column is divided into 24 terrain-following layers. BRIOS is coupled to the base of 10 of the major Antarctic ice shelves; that is, heat, salt, and momentum are transferred across the iceocean boundary layer (Beckmann et al. 1999; Hellmer 2004), with time-invariant ice shelf thicknesses, therefore assuming ice flux divergence and mass balance to be in dynamical equilibrium. A more detailed description of the model is provided in Timmermann et al. (2002). BRIOS has been validated by comparison with mooring and buoy observations regarding, for example, Weddell Gyre transport (Beckmann et al. 1999), sea ice thickness distribution and drift in the Weddell and Amundsen Seas (Timmermann et al. 2002; Assmann et al. 2005), and iceberg trajectories in the Weddell Sea (Lichey and Hellmer 2001). The modeled basal melt and freezing rates for the large ice shelves (Hellmer 2004) also agree well with the satellite-based estimates (Rignot et al. 2013). In addition, the BRIOS results are very similar to the findings of the finite-element coupled ocean-sea ice-ice shelf model (FESOM; Timmermann and Hellmer 2013), which represents the southern Weddell Sea with a resolution 2 to 3 times higher. This agreement justifies the use of the time-inexpensive BRIOS model for long integrations.
The atmospheric forcing for our simulations has been extracted from the output of the climate model HadCM3, configured with an interactive carbon cycle and vegetation employed in the ENSEMBLES project (Johns et al. 2011), for the twentieth century and the SRES-A1B simulation (Nakićevović et al. 2000). The latter is characterized by a $\mathrm{CO}_{2}$ emission scenario with atmospheric concentrations reaching 700 ppmv by the year 2100 and remaining at that level afterward. In this paper, two main experiments will be discussed that investigate the impact of 1) the twentieth-century (1880-1979) atmosphere on sea ice conditions and hydrography of the warmed-up southern Weddell Sea and 2) conditions as in the first experiment together with the modeled twentieth-century mean FRIS basal mass loss $\left(85 \mathrm{Gt} \mathrm{yr}^{-1}\right)$ prescribed for the first $10 \mathrm{yr}$ of the $100-\mathrm{yr}$ simulation. The $100-\mathrm{yr}$ forcing period has been selected to avoid contamination by the enhanced anthropogenic climate change signal toward the end of the twentieth century. The experiments start in year 2200, at the end of the SRES-A1B scenario run, supplemented by additional twentieth-century atmosphereonly simulations starting between year 2070 and 2100 . A detailed list of the nine experiments that were conducted is provided in Table 1.

\section{Results}

At the end of the BRIOS A1B-scenario simulation (year 2199), the southern Weddell Sea is controlled by a warmer and wetter atmosphere (Timmermann and Hellmer 2013), which causes 1) a retreat of the sea ice cover, limiting new sea ice formation to a narrow coastal band (Fig. 2, left column), 2) warm and fresh waters on the continental shelf (Fig. 3, left column), 3) a Filchner Trough filled with salty and warm water of open ocean origin (Fig. 4, left column), and 4) a high FRIS basal mass loss of about $1600 \mathrm{Gt} \mathrm{yr}^{-1}$ (gray curve in Fig. 5a). To consider the reversibility of the warming on the continental shelf, the impact of cooler and drier atmospheric conditions at different stages of the warm-shelf phase (Table 1, index I) was investigated by switching to the twentieth-century atmospheric forcing at various times in the period between 2070 and 2200 (Table 1, indices II to VII). The results show that, although sea ice volume quickly recovers to cold-shelf conditions (Fig. 5b), the basal mass loss approaches a new "quasi", equilibrium of around $800 \mathrm{Gt} \mathrm{yr}^{-1}$ (Fig. 5a), almost 10 times higher than the modeled present-day value of $85 \mathrm{Gt} \mathrm{yr}^{-1}$. Experiments (II-VI) approach this new state of relatively high melt rates, indicative of warm-shelf conditions, over a period of about 30 years. The exception is the simulation that starts in year 2070 (i.e., just prior to the onset of strong basal melting in the A1B 
TABLE 1. List of model experiments. Atmospheric forcing was extracted from the climate model HadCM3, a climate model configuration with an interactive carbon cycle and vegetation employed in the ENSEMBLES project (Johns et al. 2011). The SRES-A1B scenario is characterized by a $\mathrm{CO}_{2}$ emission, which causes an atmospheric concentration of 700 ppmv by the year $2100-$ after $100 \mathrm{yr}$ of simulation. The twentieth-century mean basal mass loss of the Filchner-Ronne Ice Shelf in experiment VIII corresponds to $85 \mathrm{Gt} \mathrm{yr}^{-1}$, prescribed at each sub-ice shelf grid point as the mean basal melt rate of the period 1880-1979.

\begin{tabular}{lllc}
\hline \hline Index & \multicolumn{1}{c}{ Atmospheric forcing } & \multicolumn{1}{c}{ Basal melting } & Model period \\
\hline I & SRES-A1B (Hellmer et al. 2012) & Nonconstrained & $2000-2199$ \\
II & Twentieth century (1880-1979) & Nonconstrained & $2200-99$ \\
III & Twentieth century (1880-1979) & Nonconstrained & $2100-99$ \\
IV & Twentieth century (1880-1979) & Nonconstrained & $2090-2189$ \\
V & Twentieth century (1880-1979) & Nonconstrained & $2080-2179$ \\
VI & Twentieth century (1880-1979) & Nonconstrained & $2075-2174$ \\
VII & Twentieth century (1880-1979) & Nonconstrained & $2070-2169$ \\
VIII & Twentieth century (1880-1979) & First 10 years & $2200-99$ \\
IX & & Twentieth-century mean prescribed & $2300-99$ \\
\hline
\end{tabular}

scenario; Fig. 5a, light blue). This demonstrates that strong basal melting, once initiated, supports an enhanced ocean heat transport toward the ice shelf regardless of the atmospheric conditions.

To explicitly investigate this meltwater feedback, an experiment was conducted continuing from year 2200 with the twentieth-century (1880-1979) atmosphere but also prescribing an FRIS meltwater input of $85 \mathrm{Gt} \mathrm{yr}^{-1}$ for the first $10 \mathrm{yr}$ of the 100-yr simulation (Table 1, index VIII). This equates to the twentieth-century mean melt rate for the period 1880-1979. After the melt rate constraint has been removed in year 2210, the FRIS basal mass loss and sea ice volume in the southern Weddell Sea quickly revert to their twentieth-century values
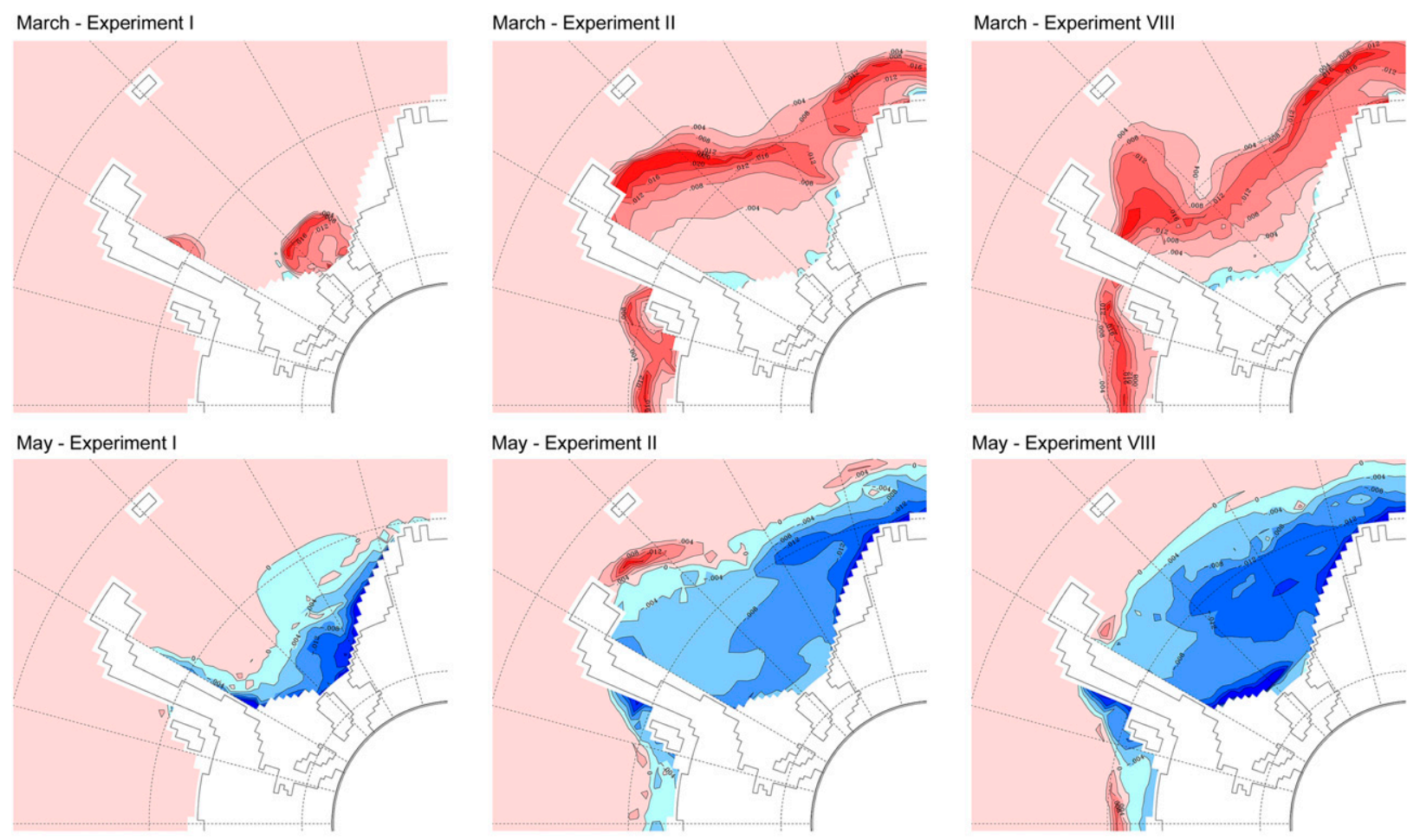

May - Experiment II

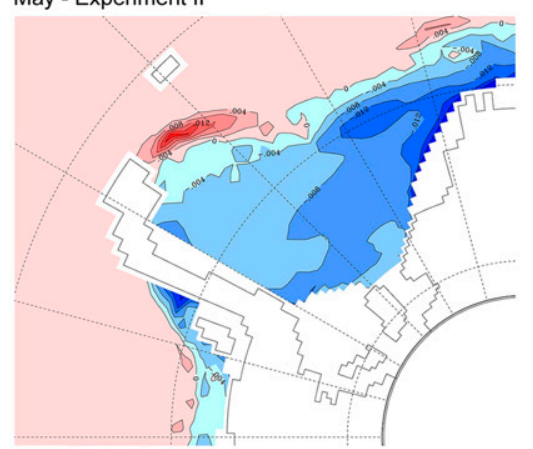

May - Experiment VIII

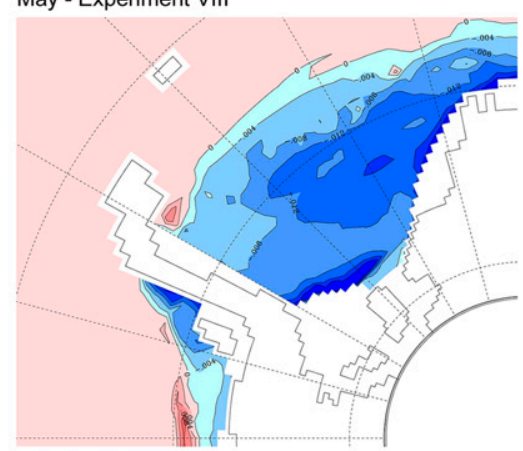

$-20$

$-16$

$-12$

$-8$

$-4$

0

4

8

12

16

$20 \mathrm{~mm} / \mathrm{d}$

FIG. 2. Distribution of sea ice melting (freezing) for representative monthly means of (top) March and (bottom) May for the last 30 years of the experiments I, II, and VIII (Table 1) showing the positive (negative) surface freshwater flux in the Weddell Sea. Sea ice melting is strongest at the sea ice edge, which retreats to the southern coastline for experiment I. Sea ice formation occurs over the whole Weddell Sea with maxima at the edges of the eastern ice shelves and the Ronne Ice Shelf. 
Year 2200

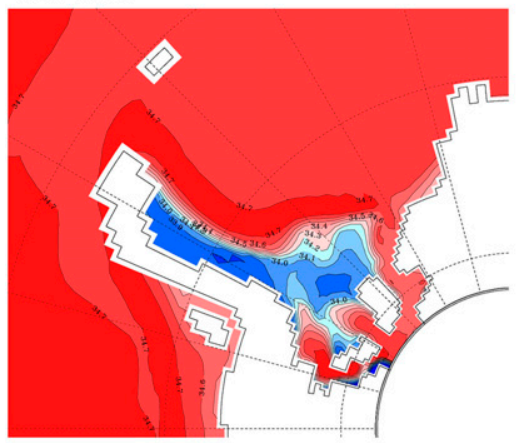

Year 2250

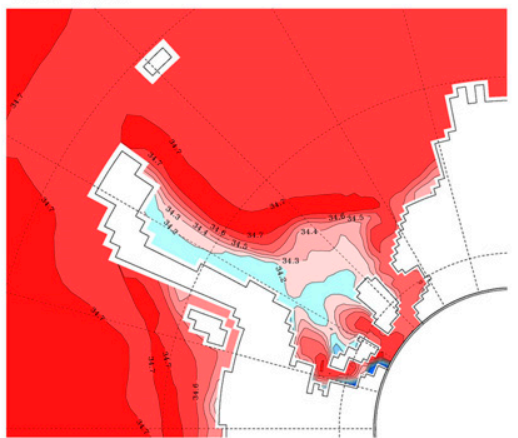

Year 2299

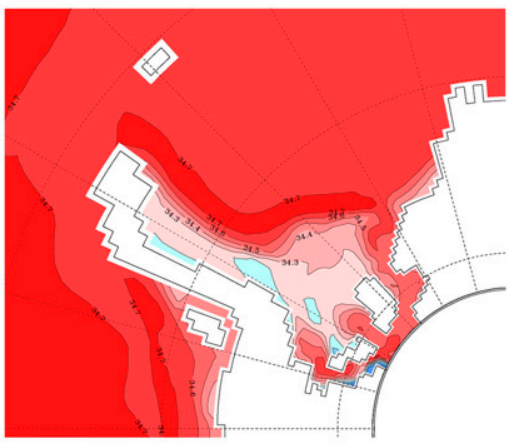

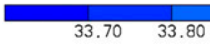
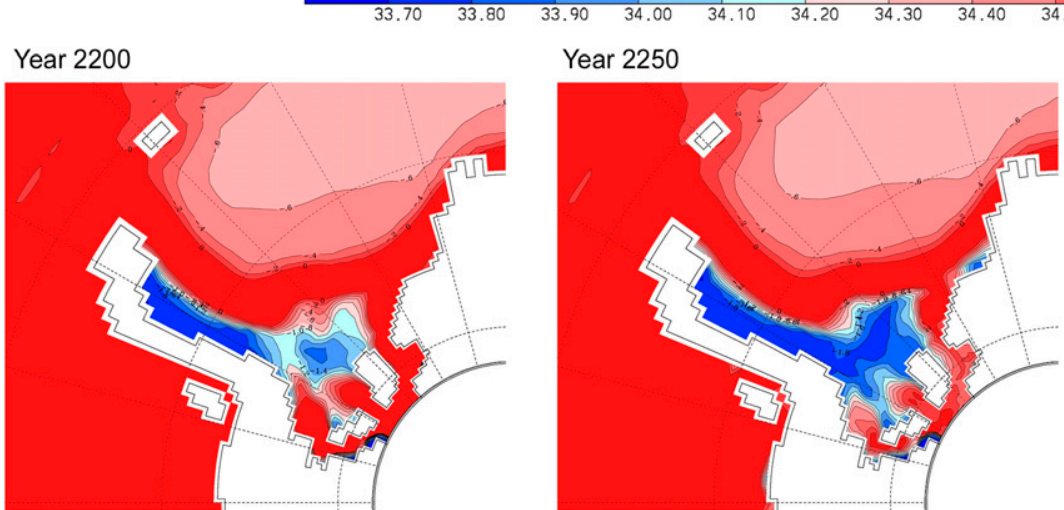

Year 2299

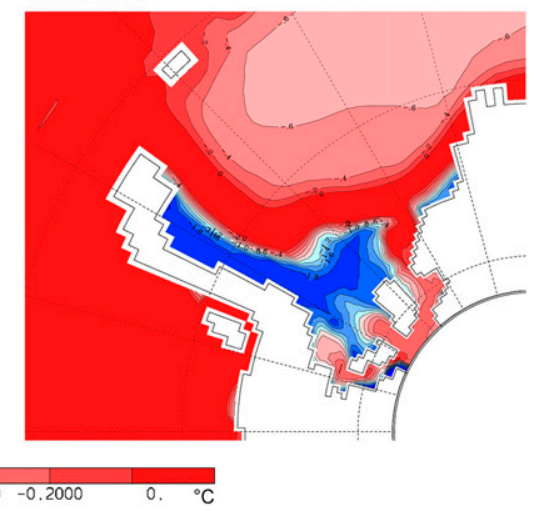

FIG. 3. Distribution of Weddell Sea bottom properties for the period 2200-99 of simulation II (Table 1). (top) Salinity and (bottom) potential temperature $\left({ }^{\circ} \mathrm{C}\right)$ for the years 2200,2250 , and 2299 as a result of BRIOS forced with the twentieth-century atmosphere of the period 1880-1979, following a more than 100-yr-long warm phase (2075-2200) on the southern Weddell Sea continental shelf.

(Figs. 5a,b). The slightly enhanced basal mass loss at the beginning is a result of heat left in the deep cavity from the warm-shelf phase. The following discussion will focus on the causes of the different magnitudes of the reduction of FRIS basal mass loss. These are strongly related to the sea ice and hydrographic conditions in the southern Weddell Sea and the glacial meltwater characteristics, which together influence the density structure in the Filchner Trough and at its sill. The discussion will also consider the robustness of the positive feedback mechanism that maintains the state of high basal melting once it has been initiated.

\section{Discussion}

\section{a. Sensitivity to twentieth-century atmospheric forcing}

For all atmospheric sensitivity experiments, the sea ice volume in the southern Weddell Sea recovers within 10 years to continue with the same interannual variability around a new quasi equilibrium of $0.8 \times 10^{3} \mathrm{~km}^{3}$ (Fig. 5b), which is slightly less than the value at the end of the twentieth century. The difference could be even larger, if the ocean would directly interact with the atmosphere. A fully coupled atmosphere-sea iceocean model might result in a different state with ocean-atmosphere feedbacks defining the sea ice characteristics and consequently the buoyancy forcing on the continental shelf. The common variability is caused by the identical forcing and shows that the polar atmosphere has prime control of sea ice conditions in the southern Weddell Sea. The increase in sea ice volume is due to the sea ice cover surviving the austral summer and displacing the strong melting at the sea ice edge off the southern continental shelf (Fig. 2, top center) and more widely spread sea ice formation during fall (Fig. 2, bottom center). Both contribute to a salinification and cooling of the lower shelf water (Fig. 3). As this water enters the FRIS cavity from the west, it slightly freshens and cools the bottom layer there, but the deep and the eastern cavity remain influenced by the inflow of warm water via the Filchner Trough (Fig. 3, right column). The temperature of this inflow, however, drops by roughly $0.8^{\circ} \mathrm{C}$, while the 


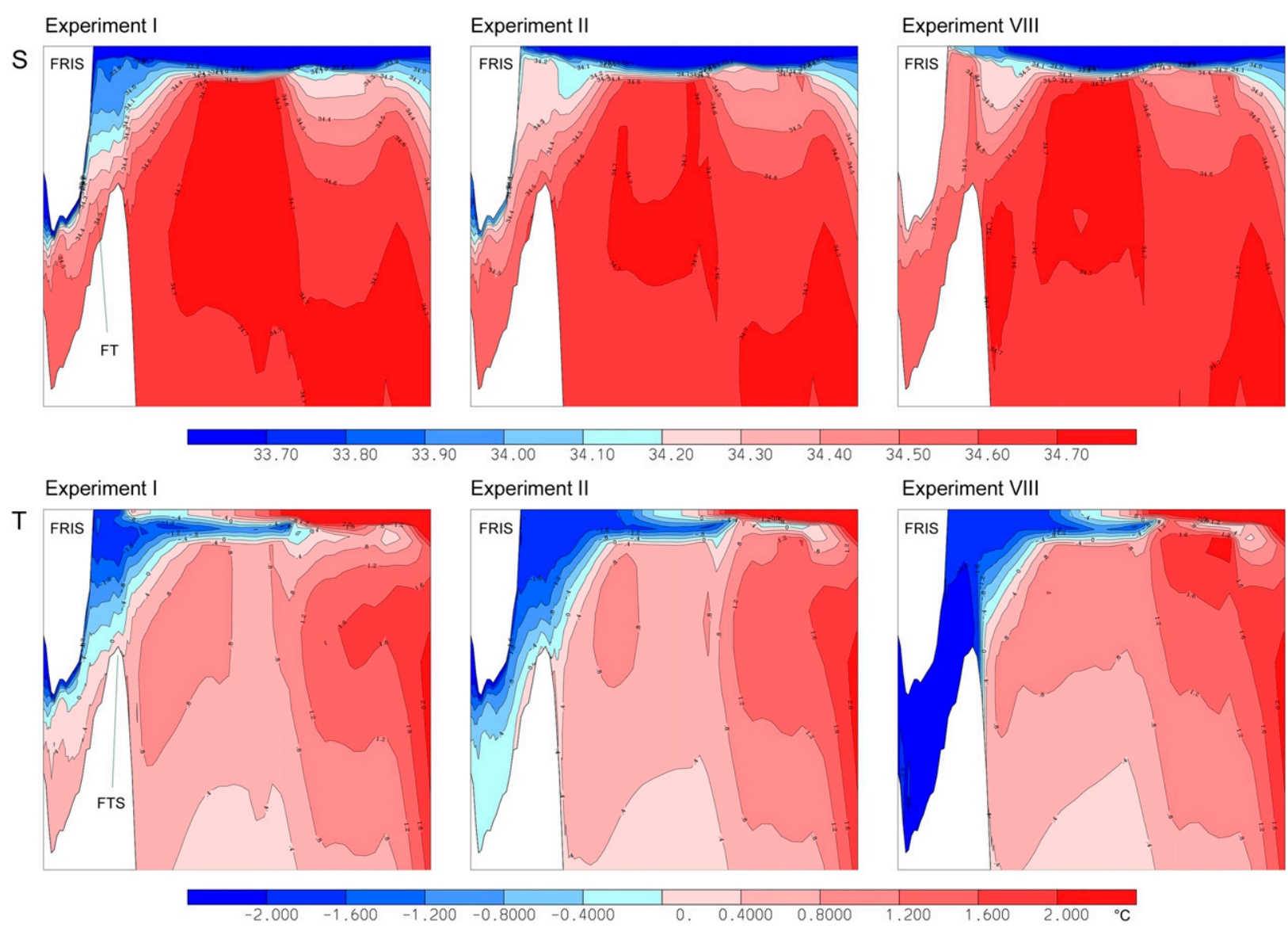

FIG. 4. Spliced meridional sections through the model domain, starting from the FRIS grounding line (left of each panel), following northward along the dashed orange arrow (Fig. 1) to the continental shelf break and continuing along circa $30^{\circ} \mathrm{W}$ up to the northern limit of the model domain at $50^{\circ} \mathrm{S}$. (top) Salinity and (bottom) potential temperature are representative for the last 30 years of the experiments I, II, and VIII (Table 1). (left) The retreat of the warm water of open ocean origin from the Filchner Trough (FT), (center) the advance of a cooler and saltier ISW, and (right) the reestablishment of today's slope front in simulation VIII. Simulation VIII also indicates remnants of deep convection near the ice shelf edge (upper right).

salinity and the thickness of the cold outflow increase (Fig. 4, center). This new warm-shelf phase seems to be stable, as an additional 100-yr forcing with the twentiethcentury atmosphere does not cause any significant changes in the southern Weddell Sea (not shown).

The close relationship between atmospheric conditions in the southern Weddell Sea and FRIS basal mass loss, via sea ice formation and salinity on the continental shelf, is demonstrated in Fig. 6a. The twentieth-century atmosphere forces the bottom salinity to increase from the A1B minimum of 34.2 (Fig. 6a, lower-right corner) to slightly above 34.4 , which seems to be a threshold value for the system to switch from the cold-shelf to the warm-shelf phase in experiment I (Table 1). Since no further salinification occurs, the BML remains around $800 \mathrm{Gt} \mathrm{yr}^{-1}$. In contrast, at the beginning of experiment VII (Table 1) bottom salinity is still above the threshold value (Fig. 6a, upper-left corner) and continues to rise to a higher end value than at the beginning of the SRES-A1B scenario run (year 2000). The difference is due to the forcing that ends in the conditions of 1980, supporting a higher shelf water salinity, while experiment I starts in 2000. As a consequence of the high salinity on the continental shelf and the missing inflow of warm waters, the BML remains at $85 \mathrm{Gt} \mathrm{yr}^{-1}$ (note that the dark-gray dots in Fig. 6a are shifted by $200 \mathrm{Gt} \mathrm{yr}^{-1}$ for better visibility).

\section{b. Sensitivity to twentieth-century basal melting}

At the end of the twentieth-century atmosphereplus-meltwater experiment (VIII) with a prescribed basal flux limited to the first 10 years (Table 1), the summer sea ice extent is similar to present-day conditions with the zone of strong melting close to the continental shelf break and sea ice formation along the southern ice shelf edge. The latter increases during fall 

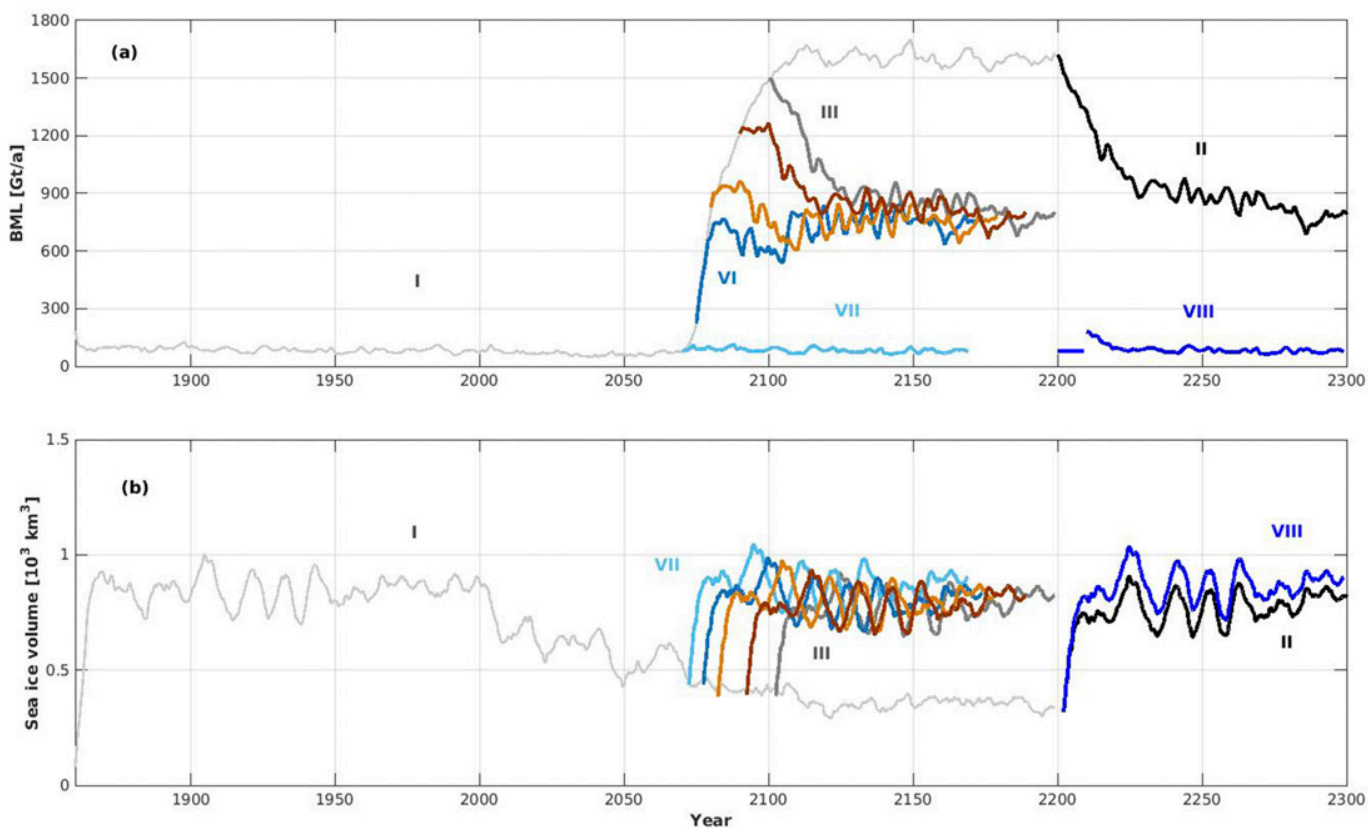

FIG. 5. Spliced time series from year 1860 to 2300 (a) BML of Fichner-Ronne Ice Shelf for the twentieth century and SRES-A1B scenario extracted from the HadCM3 climate model (I; gray), the perturbation experiments applying the twentieth-century atmosphere (1880-1979) during the warm phase starting in year 2200 (II; black), 2100 (III; dark red), 2090 (IV; brown), 2080 (V; orange), 2075 (VI; blue), and 2070 (VII; light blue). For the starting point in year 2070, the onshore flow of warm open ocean water into the Filchner Trough and thus the increase in FRIS's BML does not occur. (b) As in (a), but for sea ice volume on the southern Weddell Sea continental shelf (5-yr running mean). In addition, climatological mean basal meltwater flux (see text for details) was applied for $10 \mathrm{yr}$ only together with $100 \mathrm{yr}$ of atmospheric forcing of the period 1880-1979, starting in year 2200 (VIII; dark blue). Roman numbers indicate the simulation index according to Table 1.

and extends northeastward to cover most of the Weddell Sea (Fig. 2, right column). The salt input to the southern continental shelf due to sea ice formation is more intense than in any of the other experiments. As a result, saline and cold-shelf water reestablishes within less than 15 years. This water mass flushes the FRIS cavity from the west, replacing the warm water that had entered the cavity from the east via the Filchner Trough (Fig. 7). Here, slightly saltier (compared to experiment II) and significantly colder ISW with temperatures below the surface freezing point fills the entire trough (Fig. 4, right column), thus contributing to a further increase in density of the water masses. In parallel, the thermocline at the trough's sill deepened (possible links are discussed in section 4c), indicating that warm water of open ocean origin cannot flow anymore toward the cavity. As a consequence of the flushing of the cavity with colder, more saline water, the FRIS basal mass loss returns to the twentieth-century value of $85 \mathrm{Gt} \mathrm{yr}^{-1}$ (Fig. 5a).

The salinity-versus-BML relation shows that the southern continental shelf regains the twentieth-century salinity within a decade (Fig. 6b). A BML close to $200 \mathrm{Gt} \mathrm{yr}^{-1}$ at the beginning of the unconstrained simulation (year 2210) is due to warm water still in the cavity-its complete flushing with newly formed cold and saline shelf water takes around a decade (Fig. 7). Continuing simulation VIII (year 2300) for another 100 years with the SRES-A1B atmospheric forcing (Table 1, index IX), the southern Weddell Sea passes through the same changes as during the initial A1B simulation (Table 1, index I) - that is, a continuous freshening of the shelf water, unmodified WDW directed southward underneath the FRIS after 70 years of simulation, and a significant increase of the FRIS basal mass loss (Fig. 6b).

The rapid return from the warm-shelf phase to present-day conditions on the southern Weddell Sea continental shelf (experiment VIII) indicates that the region, including the ice shelf cavity, has a memory of roughly 15 years. However, a return to the cooler, drier atmosphere of the twentieth century on its own does not cause the system to revert to a cold-shelf phase. Instead, it approaches a new equilibrium with a BML 10 times higher than today (Fig. 5a). Nevertheless, assisted by the meltwater flowing out from the FRIS cavity, the polar atmosphere exerts the prime control on the sea ice conditions and hydrographic properties 

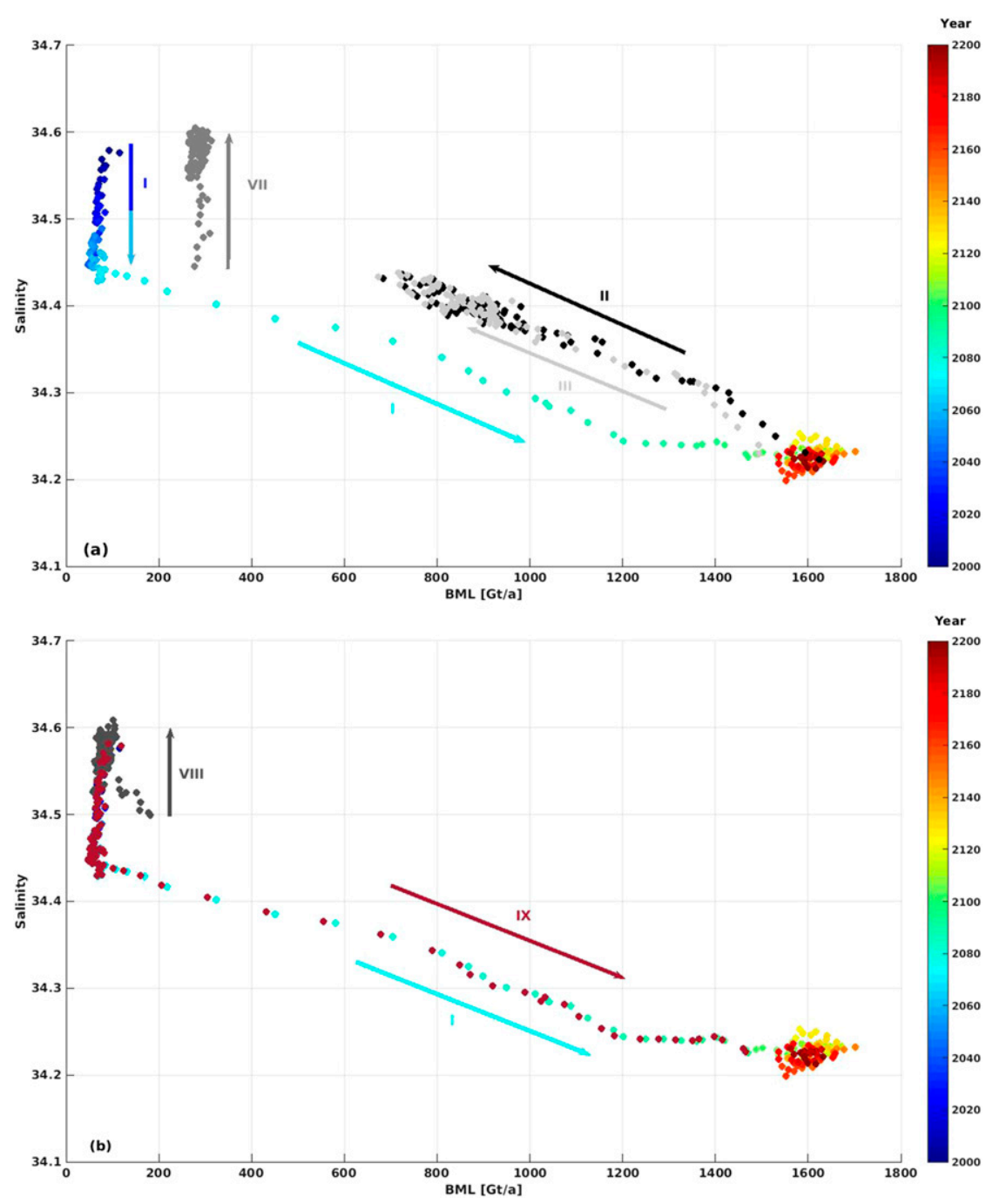

FIG. 6. Filchner-Ronne Ice Shelf basal mass loss vs mean bottom salinity in the southern Weddell Sea. (a) The SRES-A1B simulation, represented by the color-coded (year of simulation) dots, is perturbed solely by $100 \mathrm{yr}$ of twentieth-century (1880-1979) atmospheric forcing starting in year 2070 (VII; gray dots), 2100 (III; light gray dots), and 2200 (II; black dots). The gray dots of experiment VII are shifted by $200 \mathrm{Gt} \mathrm{yr}^{-1}$ for better visibility. (b) In addition to $100 \mathrm{yr}(2200-99)$ of twentieth-century atmospheric forcing, basal melting of the first $10 \mathrm{yr}$ (2200-09) is fixed to the twentieth-century FRIS mean (gray dots), followed by $90 \mathrm{yr}$ of SRES-A1B forcing (dark red dots). Arrows indicate direction in time and Roman numbers the simulation index according to Table 1.

on the southern Weddell Sea continental shelf. This interplay has a profound impact on the density structure and salinity of the shelf water column and therefore the characteristics of the ISW that results from interactions of shelf water with the FRIS base. ISW encounters open ocean water masses at the Filchner Trough sill (FTS; Fig. 1), where today it occupies most of the lower water column with a density slightly higher than the off-shelf waters (S. Ryan 2017, personal communication). Summarizing the previous experiments, the FTS seems to be a key region in the southern
Weddell Sea, hosting processes that regulate the heat transport into the FRIS cavity and therefore the mass balance of the ice shelf and the dynamics of the ice streams draining into it.

\section{c. Conditions at the Filchner Trough sill}

Here we further investigate the dynamics at the FTS. Figure 8 shows the time evolution of 1) potential temperature and meridional velocity near the bottom of the FTS, 2) the zonal in situ density gradient across the sill together with the depth of the WDW thermocline 
Year 2200

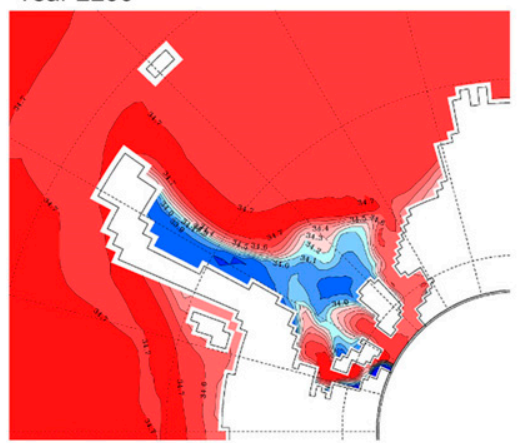

Year 2205

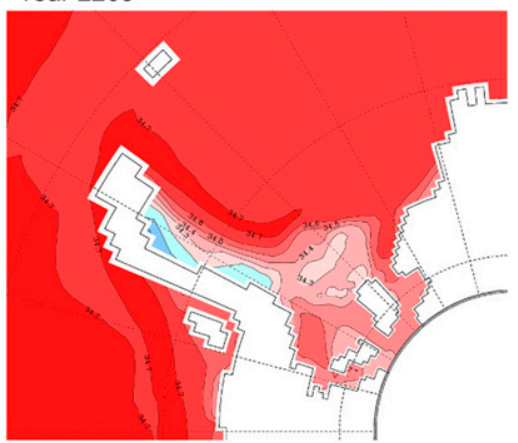

Year 2215

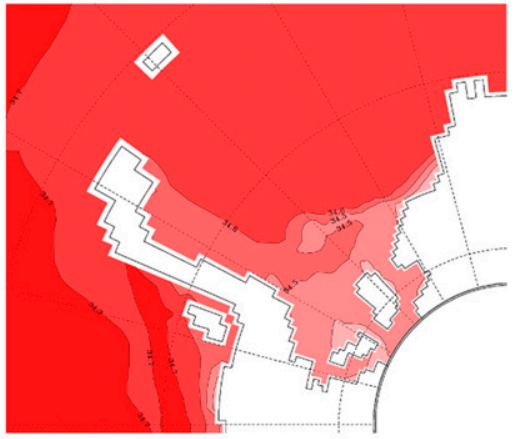

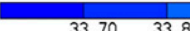

$33.70 \quad 33.80$

Year 2205
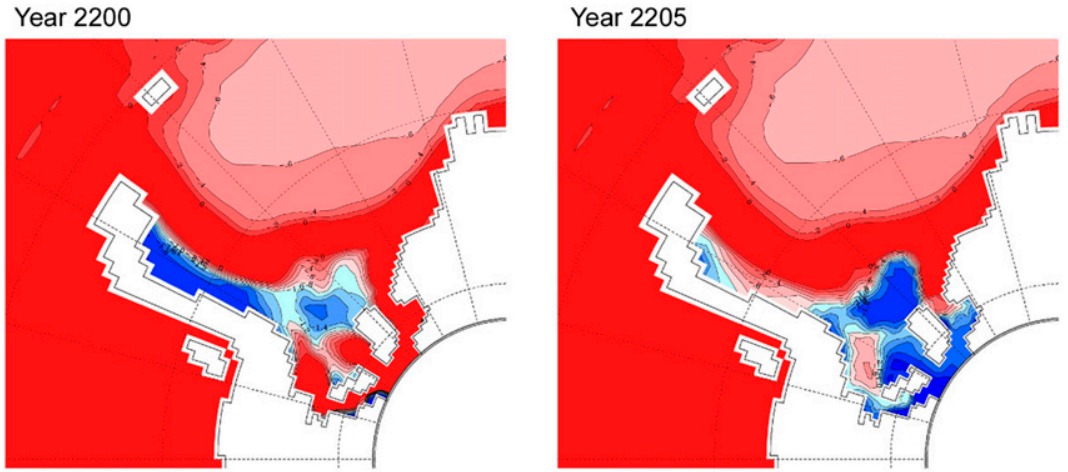

Year 2215

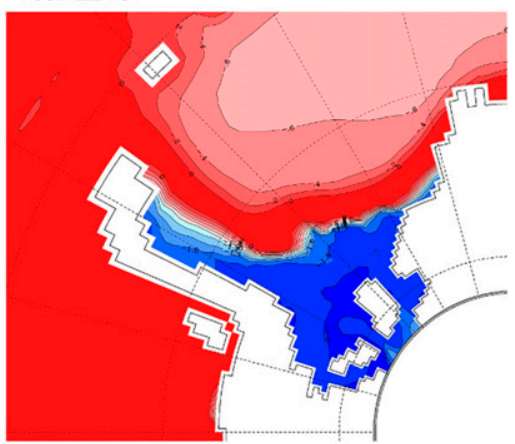

$\begin{array}{llllllllllll}-2.000 & -1.800 & -1.600 & -1.400 & -1.200 & -1.000 & -0.8000 & -0.6000 & -0.4000 & -0.2000 & 0 . & { }^{\circ} \mathrm{C}\end{array}$

FIG. 7. Distribution of Weddell Sea bottom properties for the period 2200-15 of experiment VIII (Table 1). (top) Salinity and (bottom) potential temperature $\left({ }^{\circ} \mathrm{C}\right)$ for the years 2200,2205 , and 2215 as a result of BRIOS forced for $100 \mathrm{yr}$ with the twentieth-century atmosphere of the period 1880-1979 plus for the first $10 \mathrm{yr}$ (2200-10) with mean FRIS basal melt rates of the period 1880-1979, equivalent to a basal mass loss of $85 \mathrm{Gt} \mathrm{yr}^{-1}$, following a more than 100-yr-long warm phase (2075-2200) on the southern Weddell Sea continental shelf.

across a section over the continental slope located upstream, and 3) vertical mean salinity at three positions across the trough (red stars in Fig. 1). For the period 1860-2199, the conditions at the sill evolve from a northward flow of cold $\left(-2^{\circ} \mathrm{C}\right)$ ISW, lasting until approximately year 2030 , to a persistent southward flow of warm WDW that reaches a "quasi stationary" state by about year 2100 (Fig. 8a). During the transition period between these two modes, the northward flow at the sill gradually decreases as a result of the continuous freshening of the ISW outflow, which reduces and eventually reverses the near-bottom density gradient across the sill (Fig. 8b, blue line). At the same time, and also as a response to changing atmospheric and sea ice conditions, the thermocline at the continental slope just upstream of the Filchner Trough intermittently rises above the sill depth of $600 \mathrm{~m}$ (Fig. 8b, orange line), allowing pulses of warm water to enter the trough, as it is no longer blocked by ISW. Earlier excursions of the thermocline above the sill depth also appear as warm spikes, but the nearbottom sill temperature remains dominated by the ISW outflow. The latter first starts to cease (Fig. 8a) when the salinity, which primarily determines density at low temperatures, of the ISW at the western flank of the trough falls below 34.4 (Fig. 8c, purple line; i.e., when the ISW becomes less dense than the off-shelf WDW).

However, as shown by experiment VII, the intermittent pulses of warm water do not increase basal melting sufficiently to trigger the self-amplifying feedback, which dominates the enhanced melting response in the sensitivity experiments. Only an elevated thermocline at around year 2070 together with persistent southward flow at the sill causes a continuous access of unmodified WDW to the continental shelf. The freshening due to the resulting glacial meltwater is sufficient to reverse the full-depth density gradient across the trough. This intensifies the near-bottom southward flow, which transports yet more WDW toward the FRIS cavity. The reversal of the depthaveraged salinity gradient across the trough between 2070 and 2075 (Fig. 8c) can also be seen in the zonal sections of hydrographic properties (Fig. 9), showing the successive change of the density structure across the Filchner Trough sill before, during, and after the 
(a)

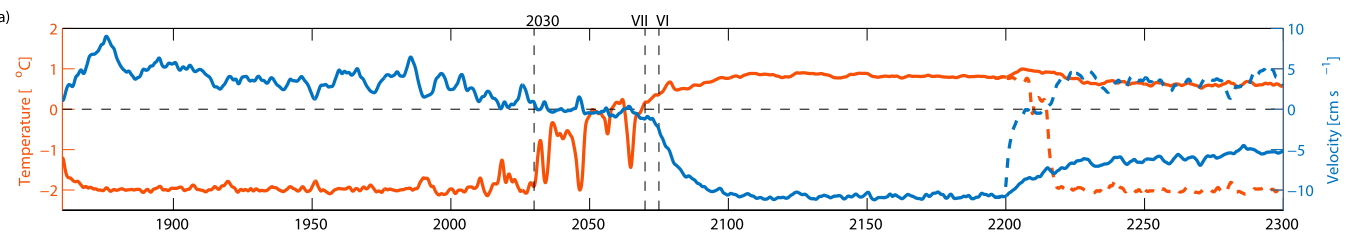

(b)

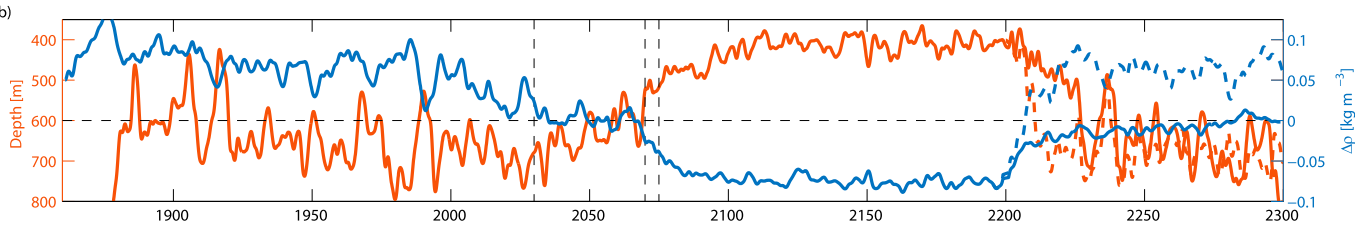

(c)

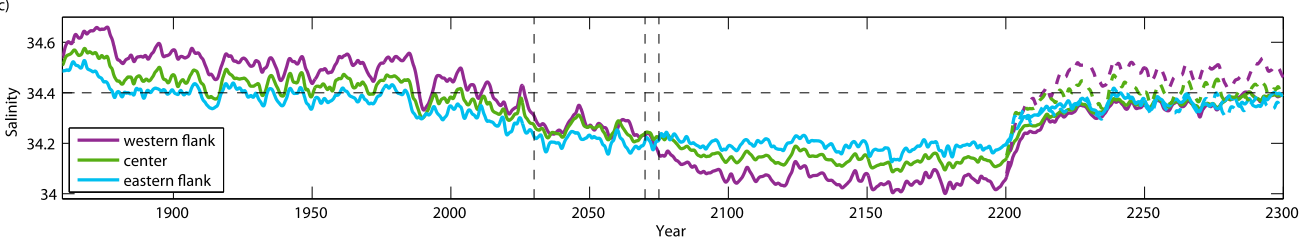

FIG. 8. Time evolution of various parameters at/near the Filchner Trough sill (red stars in Fig. 1) (a) near-bottom potential temperature and meridional velocity (positive represents northward flow), (b) zonal in situ density gradient across the sill (west minus east), averaged below 250-m depth, complemented by depth of the WDW thermocline (defined as $0^{\circ} \mathrm{C}$ isotherm) at the upstream continental slope, and (c) depth-averaged salinity at three positions across the trough. Solid curves show the simulation period 1860-2199, continued with $100 \mathrm{yr}$ of the twentieth-century atmosphere sensitivity experiment (II). Dashed curves represent the meltwater sensitivity experiment (VIII). Vertical lines indicate onset of the warm pulses being concurrent with cease of the ISW outflow across the sill (2030), as well as the starting points of the sensitivity experiments VII (2070) and VI (2075), which frame the transition of the system into the meltwater-dominated warm-shelf phase.

transition to the warm-shelf phase. Although the erosion of the dense ISW allows traces of warm open ocean water to begin entering the trough near the bottom as early as 2040 , it is only from 2070 onward that there is enough WDW in the FRIS cavity to produce the fresh and buoyant outflow along the western flank of the trough that can reverse the density gradient at the sill (Figs. 8b,c).

Once the inflow of WDW dominates basal melting, the southward flow at the FTS sustains the access of WDW, and the system cannot revert to the low-melting state unless the production of buoyant meltwater stops. For the sensitivity experiment II (Table 1 ), the change to an increased rate of sea ice formation and therefore an increase in the salt input to the southern Weddell Sea continental shelf increases the salinity in the Filchner Trough (Fig. 8c). This weakens the negative density gradient across the trough (Fig. 8b), but since salinity stays below the evident threshold of 34.4, ISW remains less dense than the offshore WDW and maintains a southward flow at the FTS (Fig. 8a). Within the first 20 years the $0^{\circ} \mathrm{C}$ isotherm drops below the sill depth (Fig. 8b). Consequently, water that is slightly cooler, but still significantly above surface freezing, enters the trough across the sill, where the southward flow is retained at nearly half its previous velocity (Fig. 8a). This substantial flow of warm water into the FRIS cavity supports a BML of roughly $800 \mathrm{Gtyr}^{-1}$. The same changes at the sill take place for all the experiments (III-VI) with the details dependent on the point at which the twentieth-century atmosphere is applied. The exception is experiment VII (starting in year 2070) in which less warm water has reached the ice shelf cavity; in that case, the salinity on the southern continental shelf returns to twentieth-century levels within 10 years, reasserting the "blocking effect" of the ISW outflow at the FTS.

For sensitivity experiment VIII, which artificially restores the FRIS BML to the twentieth-century value of $85 \mathrm{Gt} \mathrm{yr}^{-1}$ (for the first 10 years; Table 1), the response at the center of the FTS is much quicker than for experiment II. During the first 10 years (2200-09), the salinity at the western flank of the trough increases and the density gradient reverses to pre-2030 values (Figs. 8b,c, dashed lines). At the same time, the depth of the $0^{\circ} \mathrm{C}$ isotherm drops below the sill, and, more important for the cavity's heat content, the flow across the sill reverses from inflow to outflow. The trends continue during the unconstrained phase (2210-99) of this experiment until the twentieth-century values are reached. This includes the passing of the salinity threshold of 34.4 and the main flow into the cavity switching from the Filchner Trough to the front of the Ronne Ice Shelf (not 

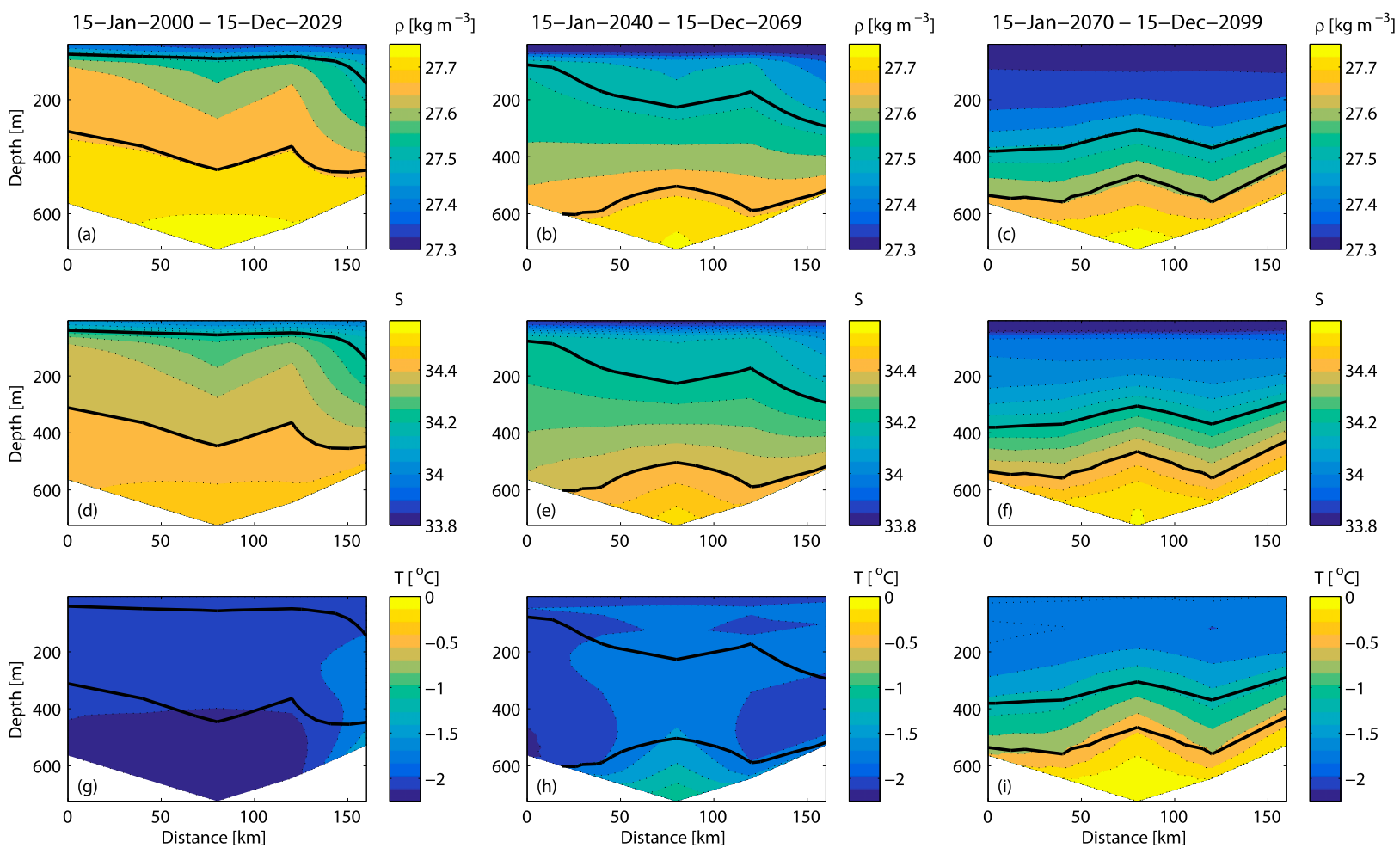

FIG. 9. Zonal section across the Filchner Trough sill (looking north) of (a)-(c) in situ density, (d)-(f) salinity, and (g)-(i) potential temperature for time periods before, during, and after the transition into the warm-shelf phase. Black contours show the 34.2 and 34.4 isohalines, illustrating the reversal of the cross-trough density gradient, caused by the freshening of the ISW outflow.

shown). It is then the shelf water at the surface freezing point that drives the melting beneath FRIS, limiting its

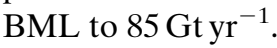

\section{Conclusions}

Our experiments indicate that the link between the hydrography on the southern Weddell Sea continental shelf and melt rates beneath the Filchner-Ronne Ice Shelf is controlled by a positive feedback mechanism: Once the reversal of the near-bottom density gradient across the Filchner Trough, together with a rising coastal thermocline, facilitates the direct inflow of the slope current into the trough, warm deep water flushes the ice shelf cavity, causing its warming, enhanced basal mass loss, and a vigorous outflow of glacial meltwater. The latter further freshens the shelf water and thus maintains a density and flow structure at the sill that supports further access of warm water to the ice shelf cavity. The increase in basal melting accelerates the cavity circulation, drawing in even more warm water of open ocean origin-a self-intensifying mechanism. Although the initial trigger for this transition is freshening on the continental shelf as a result of atmosphere-ocean interactions, once the system is in the warm-shelf phase, the only way to stop the inflow of the warm water is to return to twentiethcentury atmospheric conditions and to reduce the meltwater input. At first, the latter could be realized by a reduction in the floating portion of the ice sheet. However, the resulting loss of buttressing of the inland ice sheet would accelerate the draining ice streams. The discharge of ice from the relevant catchment basin and a significant contribution to global sea level will be inevitable.

The existence of this tipping point strongly depends on the atmospheric conditions projected for the region (Timmermann and Hellmer 2013). The latter bear some uncertainty, as evident from the spread among the climate scenarios and the different model realizations. The uncertainty in the atmospheric projections and the fact that the ocean models used here are imperfect prohibit us from predicting exactly when changes in the southern Weddell Sea discussed here will occur. However, observations suggest that the core of the WDW near the continental shelf break is rising (Schmidtko et al. 2014) and derivatives of WDW can already be traced to the Filchner ice front (Darelius et al. 2016). A reduced heat transport into the Filchner Trough, due to a cooling of the water masses feeding 


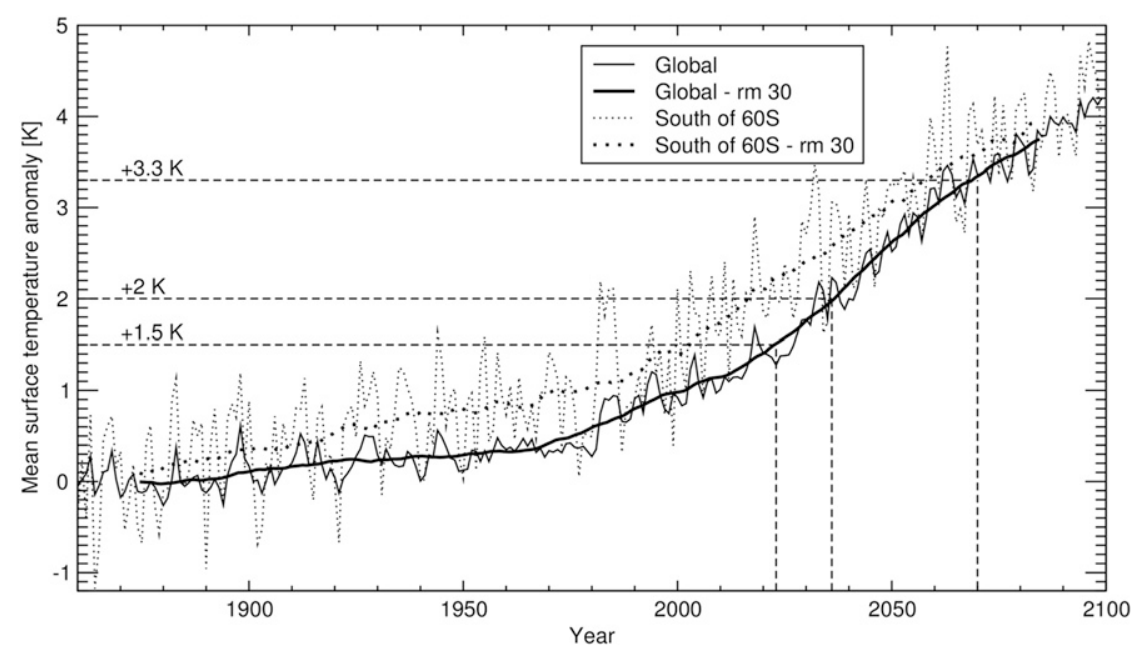

FIG. 10. Evolution of mean surface temperature anomaly (with respect to the preindustrial value) in the HadCM3 twentieth-century-SRES-A1B scenario simulation for the period 1860 2100 , separated into global (solid lines) and Southern Hemisphere south of $60^{\circ} \mathrm{S}$ (dashed lines). The smooth curves represent the 30-yr running mean ( $\mathrm{rm} \mathrm{30).}$

the slope current in the eastern Weddell Sea, is not very likely given the poleward intensification of the westerly winds with the possibility of a southerly displacement of the ACC during the twenty-first century (Meijers et al. 2012). Such a shift would rather bring warmer water to the eastern Weddell Sea and ultimately to the southern continental shelf. In addition, once deep ocean heat penetrates into the Filchner Trough it cannot easily be vented to the atmosphere by coastal polynyas (Khazendar et al. 2013) because the fresh surface layer, owing to the increased meltwater input, stabilizes the water column and thus hampers deep convection (Fig. 4). Together with the absence of a cold ISW outflow, this guarantees that most of the heat reaches the Filchner sub-ice cavity supporting accelerated basal melting and, eventually, grounding line retreat (Wright et al. 2014). Our results indicate that this process might be irreversible as long as basal areas provide sufficient glacial melt to freshen the continental shelf waters. Although the results are based on the output of a circumpolar model of medium resolution, they suggest a physically plausible mechanism for the existence of a climate tipping point in the southern Weddell Sea, which needs further investigation by means of higher-resolution models and long-term observations. In addition to the uncertainty in the projections of atmospheric forcing and the related oceanic response, the shape of the subglacial bedrock topography is essential for projecting future ice stream/sheet behavior (Favier et al. 2014) and global sea level rise. Therefore, long-term hydrographic monitoring of the Antarctic marginal seas should be combined with geophysical and glaciological surveys on the floating and resting ice sheet as part of future studies in Antarctica.

The advance of ocean heat into the Filchner Trough finally happens in the HadCM3 SRES-A1B experiment around the year 2070 with sporadic pulses occurring earlier (around 2020; see Fig. 8), which barely reach the ice shelf front. An analysis of the annual mean global surface air temperature of the HadCM3 SRES-A1B scenario simulation (Fig. 10) reveals that the global mean surface temperature relative to the preindustrial value has increased by about $3.3^{\circ} \mathrm{C}$ around the year 2070 . At the same time, the surface south of $60^{\circ} \mathrm{S}$ has warmed by about the same amount (no polar amplification; dashed lines in Fig. 10), and a $2^{\circ} \mathrm{C}$ southern warming is reached in 2020. While the pulses of heat do not reach the deep cavity in the BRIOS simulation, for the higherresolution finite-element model FESOM the pulse around 2020 causes basal melting to increase to $400 \mathrm{Gt} \mathrm{yr}^{-1}$ (Fig. S5 in Hellmer et al. 2012). With all caution necessary, because 1) our results are deduced only from one climate model and one realization of the SRES-A1B scenario and 2) certainly shortcomings in both coupled ice-ocean models (BRIOS and FESOM) exist, a limitation of the global warming to $2^{\circ} \mathrm{C}$ bears the risked of destabilizing the Weddell Sea's largest ice shelf. However, prior to 2020 all SRES scenarios are very close with respect to their $\mathrm{CO}_{2}$ concentration, which reaches about 400 ppmv in 2020. In March 2016 the seasonal-cycle-corrected $\mathrm{CO}_{2}$ concentration at Mauna Loa amounted to 403 ppmv (http://www.esrl. noaa.gov/gmd/ccgg/trends/). 
Acknowledgments. We thank C. Wübber and W. Cohrs for providing a stable computer performance at the Alfred Wegener Institute Helmholtz Centre for Polar and Marine Research (AWI), the ice2sea community for helpful discussions during project meetings, M. V. Caspel for constructive comments during preparation of the manuscript, and K. Nicholls for critical reading and many suggestions for improvement of the submission. Present funding for R.T. by the Helmholtz Climate Initiative REKLIM (Regional Climate Change), a joint research project of the Helmholtz Association of German research centers (HGF), is gratefully acknowledged. This work was supported by funding to the ice2sea program from the European Union Seventh Framework Programme Grant 226375.

\section{REFERENCES}

Årthun, M., K. W. Nicholls, K. Makinson, M. A. Fedak, and L. Boehme, 2012: Seasonal inflow of warm water onto the southern Weddell Sea continental shelf, Antarctica. Geophys. Res. Lett., 39, L17601, doi:10.1029/2012GL052856.

Assmann, K. M., H. H. Hellmer, and S. S. Jacobs, 2005: Amundsen Sea ice production and transport. J. Geophys. Res., 110, C12013, doi:10.1029/2004JC002797.

Beckmann, A., H. Hellmer, and R. Timmermann, 1999: A numerical model of the Weddell Sea: Large scale circulation and water mass distribution. J. Geophys. Res., 104, 23 375-23 391, doi:10.1029/1999JC900194.

Darelius, E., I. Fer, and K. W. Nicholls, 2016: Observed vulnerability of Filchner-Ronne Ice Shelf to wind-driven inflow of warm deep water. Nat. Commun., 7, 12300, doi:10.1038/ ncomms12300.

Depoorter, M. A., J. L. Bamber, J. A. Griggs, J. T. M. Lenaerts, S. R. M. Ligtenberg, M. R. van den Broeke, and G. Moholdt, 2013: Calving fluxes and basal melt rates of Antarctic ice shelves. Nature, 502, 89-92, doi:10.1038/nature12567.

Favier, L., and Coauthors, 2014: Retreat of Pine Island Glacier controlled by marine ice-sheet instability. Nat. Climate Change, 4, 117-121, doi:10.1038/nclimate2094.

Foldvik, A., T. Gammelsrød, and T. Tørresen, 1985: Circulation and water masses on the southern Weddell Sea shelf. Oceanology of the Antarctic Continental Shelf, S. S. Jacobs, Ed., Antarctic Research Series, Vol. 43, Amer. Geophys. Union, 5-20.

_ , and Coauthors, 2004: Ice shelf water outflow and bottom water formation in the southern Weddell Sea. J. Geophys Res., 109, C02015, doi:10.1029/2003JC002008.

Gill, A. E., 1973: Circulation and bottom water production in the Weddell Sea. Deep-Sea Res., 20, 111-140.

Grosfeld, K., M. Schröder, E. Fahrbach, R. Gerdes, and A. Mackensen, 2001: How iceberg calving and grounding change the circulation and hydrography in the Filchner Ice Shelf-ocean system. J. Geophys. Res., 106, 9039-9055, doi:10.1029/2000JC000601.

Haid, V., and R. Timmermann, 2013: Simulated heat flux and sea ice production at coastal polynyas in the southwestern Weddell Sea. J. Geophys. Res. Oceans, 118, 2640-2652, doi:10.1002/ jgrc.20133.

Hattermann, T., L. H. Smedsrud, O. A. Nøst, J. M. Lilly, and B. K. Galton-Fenzi, 2014: Eddy-resolving simulations of the Fimbul Ice Shelf cavity circulation: Basal melting and exchange with open ocean. Ocean Modell., 82, 28-44, doi:10.1016/ j.ocemod.2014.07.004.

Hellmer, H. H., 2004: Impact of Antarctic ice shelf melting on sea ice and deep ocean properties. Geophys. Res. Lett., 31, L10307, doi:10.1029/2004GL019506.

_ , F. Kauker, R. Timmermann, J. Determann, and J. Rae, 2012: Twenty-first-century warming of a large Antarctic ice-shelf cavity by a redirected coastal current. Nature, 485, 225-228, doi:10.1038/nature11064.

Jacobs, S. S., A. Jenkins, C. F. Giulivi, and P. Dutrieux, 2011: Stronger ocean circulation and increased melting under Pine Island Glacier ice shelf. Nat. Geosci., 4, 519-523, doi:10.1038/ngeo1188.

Johns, T. C., and Coauthors, 2011: Climate change under aggressive mitigation: The ensembles multi-model experiment. Climate Dyn., 37, 1975-2003, doi:10.1007/ s00382-011-1005-5.

Khazendar, A., M. P. Schodlok, I. Fenty, S. R. M. Ligtenberg, E. Rignot, and M. R. van den Broeke, 2013: Observed thinning of Totten Glacier is linked to coastal polynya variability. Nat. Commun., 4, 2857, doi:10.1038/ncomms3857.

Lichey, C., and H. H. Hellmer, 2001: Modeling giant-iceberg drift under the influence of sea ice in the Weddell Sea, Antarctica. J. Glaciol., 47, 452-460, doi:10.3189/172756501781832133.

Meijers, A. J. S., E. Shuckburgh, N. Bruneau, J.-B. Sallee, T. J. Bracegirdle, and Z. Wang, 2012: Representation of the Antarctic Circumpolar Current in the CMIP5 climate models and future changes under warming scenarios. J. Geophys. Res., 117, C12008, doi:10.1029/2012JC008412.

Nakayama, Y., M. Schröder, and H. H. Hellmer, 2013: From circumpolar deep water to the glacial meltwater plume on the eastern Amundsen Shelf. Deep-Sea Res., 77, 50-62, doi:10.1016/ j.dsr.2013.04.001.

Nakićevović, N., and Coauthors, 2000: Special Report on Emissions Scenarios. Cambridge University Press, 599 pp.

Nicholls, K. W., 1997: Predicted reduction in basal melt rates of an Antarctic ice shelf in a warmer climate. Nature, 388, 460-462, doi:10.1038/41302.

, S. Østerhus, K. Makinson, and M. R. Johnson, 2001: Oceanographic conditions south of Berkner Island, beneath Filchner-Ronne Ice Shelf, Antarctica. J. Geophys. Res., 106, 11 481-11 492, doi:10.1029/2000JC000350.

_- L. Boehme, M. Biuw, and M. A. Fedak, 2008: Wintertime ocean conditions over the southern Weddell Sea continental shelf. Geophys. Res. Lett., 35, L21605, doi:10.1029/ 2008GL035742.

Nøst, O. A., M. Biuw, V. Tverberg, C. Lydersen, T. Hattermann, Q. Zhou, L. H. Smedsrud, and K. M. Kovacs, 2011: Eddy overturning of the Antarctic Slope Front controls glacial melting in the eastern Weddell Sea. J. Geophys. Res., 116, C11014, doi:10.1029/2011JC006965.

Orsi, A. H., T. Whitworth III, and W. D. Nowlin Jr., 1995: On the meridional extent and fronts of the Antarctic Circumpolar Current. Deep-Sea Res., 42, 641-673, doi:10.1016/ 0967-0637(95)00021-W.

Rignot, E., S. S. Jacobs, J. Mouginot, and B. Scheuchl, 2013: Ice shelf melting around Antarctica. Science, 341, 266-270, doi:10.1126/science. 1235798.

Ryan, S., M. Schröder, O. Huhn, and R. Timmermann, 2016: On the warm inflow at the eastern boundary of the Weddell Gyre. Deep-Sea Res., 107, 70-81, doi:10.1016/j.dsr.2015.11.002.

Schmidtko, S., K. J. Heywood, A. F. Thompson, and S. Aoki, 2014: Multidecadal warming of Antarctic waters. Science, 346, doi:10.1126/science. 1256117. 
Schröder, M., and E. Fahrbach, 1999: On the structure and the transport in the eastern Weddell Gyre. Deep-Sea Res. II, 46, 501-527, doi:10.1016/S0967-0645(98)00112-X.

Stewart, A. L., and A. F. Thompson, 2015: Eddy mediated transport of warm Circumpolar Deep Water across the Antarctic shelf break. Geophys. Res. Lett., 42, 432-440, doi:10.1002/ 2014GL062281.

Sverdrup, H. U., 1954: The currents off the coast of Queen Maud Land. Norw. J. Geogr., 14, 239-249, doi:10.1080/00291955308542731.

Timmermann, R., and H. H. Hellmer, 2013: Southern Ocean warming and increased ice shelf basal melting in the twentyfirst and twenty-second centuries based on coupled ice-ocean finite-element modelling. Ocean Dyn., 63, 1011-1026, doi:10.1007/s10236-013-0642-0.
— A. Beckmann, and H. H. Hellmer, 2002: Simulations of iceocean dynamics in the Weddell Sea: 1 . Model configuration and validation. J. Geophys. Res., 107, 3024, doi:10.1029/2000JC000741.

- , and Coauthors, 2010: A consistent data set of Antarctic ice sheet topography, cavity geometry, and global bathymetry. Earth Syst. Sci. Data, 2, 261-273, doi:10.5194/essd-2-261-2010.

Wright, A. P., and Coauthors, 2014: Sensitivity of the Weddell Sea sector ice streams to sub-shelf melting and surface accumulation. Cryosphere, 8, 2119-2134, doi:10.5194/ tc-8-2119-2014.

Zhou, Q., T. Hattermann, O. A. Nøst, M. Biuw, K. M. Kovacs, and C. Lydersen, 2014: Wind-driven spreading of fresh surface water beneath ice shelves in the eastern Weddell Sea. J. Geophys. Res. Oceans, 119, 3818-3833, doi:10.1002/2013JC009556. 